\title{
A PRELIMINARY CENSUS OF THE MACROFUNGI OF MT WELLINGTON, TASMANIA - THE NON-GILLED BASIDIOMYCOTA
}

\author{
by Genevieve M. Gates and David A. Ratkowsky
}

(with two appendices)

\begin{abstract}
GA'TES, G. M. \& RA'TKOWSKY, D. A., 2004 (29:x): A preliminary census of the macrofungi of Mt Wellington, Tasmania - the non-gilled Basidiomycota. Papers and Proceedings of the Royal Society of Tasmania 138: 53-59. https://doi.org/1 0.26749/rstpp.138.53 ISSN 0080-4703. School of Plant Science, University of Tasmania, Private Bag 55, Hobart, Tasmania 7001, Australia (GMG*); School of Agricultural Science, University of Tasmania, Private Bag 54, Hobart, Tasmania 700 1, Australia (DAR). ${ }^{*}$ Author for correspondence.
\end{abstract}

This work is a further contribution towards documenting the macrofungi of Mt Wellington. An earlier publication was confined to 130 named and described species of 'agarics', or gilled fungi. The focus of the present paper is on the non-gilled Basidiomycota with the exception of the sequestrate species, which will be the subject of a separate study. A total of 65 non-gilled species is included here. Further, the acquisition of recent inf $\bullet$ rmation has added 11 species to the previous list of gilled fungi and enabled two of the names to be revised.

Key Words: Macrofungi, Mt Wellington (Tasmania), non-gilled, Basidiomycota, polypores, boletes, crust fungi, coral fungi, puffballs, stinkhorns, spine fungi, jelly fungi.

\section{INTRODUCTION}

A preliminary census of the Mt Wellington 'agarics' identified 130 species of gilled fungi (Ratkowsky \& Gates 2002). In this paper, the authors deal with almost all of the remaining previously-named and described Basidiomycota of the macrofungi that were not included in Ratkowsky \& Gates (2002). Thus, fungi commonly referred to as 'polypores', 'boletes', 'shelf or crust fungi', 'coral fungi', 'puffballs', 'stinkhorns', 'spine fungi' and 'jelly fungi' are treated here, the exception being sequestrate fungi ('earthballs' or trufflelike fungi), which will be the subject of a separate study. The present work was facilitated by the recent publication of the second part of a comprehensive catalogue and bibliography of Australian fungi (May et al. 2003), which completed the listing of all the validly named larger basidiomycetes reported to occur in Australia.

The taxonomy of the larger homobasidiomycetes, which includes the mushrooms and related fungi, was based in the nineteenth century upon the Friesian system with its origins in Persoon (1801). Orders were delimited on the gross morphology of the fruiting bodies and their anatomical features, i.e., whether the fungi were, using informal terms, gilled, poroid, jelly-like, etc. These groupings had the advantage of easy application in the field, making ready recognition the prime factor, ignoring phylogenetic considerations. This became the dominant approach to the classification of homobasidiomycetes until the late 1980s, when attention turned towards the use of DNA to determine phylogenetic relationships. Ratkowsky \& Gates (2002) used an old-fashioned concept of Agaricales, which delimited that Order as fungi with gills. Thus, genera such as Lactarius, Lentinellus and Russula were included in Agaricales, although they are now placed in Russulales (Kirk et al. 2001). In contrast, modern studies using nucleotide sequence data show a close affinity of 'puffballs' such as Bovista and Lycoperdon with the 'agarics' Agaricus and Lepiota (Moncalvo et al. 2002), so that they should all be grouped into Agaricales in a phylogenetic classification. Hence, some of the groupings of genera into Orders in appendices 1 and 2 may appear surprising, these following
Kirk et al. (2001). One example of this contrast between morphological and phylogenetic classification is that the genera Clavaria, Clavicorona, Clavulina and Ramaria, all considered informally as 'coral fungi', are found in four different orders in appendix 1.

\section{MATERIALS AND METHODS}

The survey zones are those of Ratkowsky \& Gates (2002), which includes a map of the survey area, details of the tracks followed and descriptions of the habitats. Fieldwork began on 1 January 1994 and was completed on 31 December 2003. During that time, 249 forays were conducted on Mt Wellington. Material collected was macroscopically described within 24 hours of collection and examined microscopically. Speciesidentification was madeby comparison of the detailed macro and micro descriptions with those of published species in the scientific literature. Voucher material for each species has been deposited in the Tasmanian Herbarium (HO) and, wherever sufficient material was available, in the National Herbarium of Victoria (MEL).

\section{RESULTS}

The list of non-gilled species in appendix 1 is confined to those taxa that have been validly named and described. This was the approach taken in Ratkowsky \& Gates (2002). Hence, the names of the 65 species listed in appendix 1 may be found either in May \& Wood (1997) or May etal. (2003) or as updated by the interactive catalogue of fungi on the Royal Botanic Gardens Melbourne website (www.rbg.vic. gov.au). The species are arranged alphabetically within each of ten Orders, these conforming to the list given in Kirk et al. (2001). Wherever photographs and/or illustrations exist in readily available sources for the species listed in appendix 1 , references to these are given.

Four further species of Mycena can be added to the list of gilled fungi in Ratkowsky \& Gates (2002), and one name change made, as a result of the recent monograph 
on that genus by Grgurinovic (2003). In addition, the three species of Lentinellus in Tasmania treated by Gates \& Ratkowsky (2003) all occur on Mt Wellington and are included in appendix 2, these species having been omitted from Ratkowsky \& Gates (2002). A few additional gilled species are included in appendix 2, resulting either from recent collections or from identifications or nomenclatural changes made possible by recent publications.

\section{DISCUSSION}

As stressed in Ratkowsky \& Gates (2002), the study and documentation of macrofungal species in Australia is in its early stages. Various problems in taxonomy and identification still need to be resolved. Consider, for example, the genus of 'jelly fungi' Calocera (Fr. : Fr.) Fr., which produces gregarious, rod-like fruit bodies on wood over a wide range of altitudes on Mt Wellington and in other Tasmanian wet forests. Four Calocera species with a Tasmanian type are listed in May et al. (2003), viz. C. australis McNabb, C. candida Lloyd, C. cuneata Lloyd, and C. lutea (Massee) McNabb. Identifying the specimens to species level is difficult in the absence of a definitive study of the Australian species of the genus, and is beyond the scope of this survey.

The 65 species in appendix 1 , the 11 additional gilled species in appendix 2, plus the 130 species of 'agarics' in the appendix of Ratkowsky \& Gates (2002), result in a list for Mt Wellington of 206 species. If all the undescribed but recognisable taxa were added to the list, the total would be considerably higher. It is not possible to make an estimate of the total number of macrofungi species on Mt Wellington at the present time. Many additional taxonomic studies will need to be undertaken, especially on species-rich families, before the species count of $\mathrm{Mt}$ Wellington macrofungi can be expected to stabilise.

\section{ACKNOWLEDGEMENT}

We thank Dr Leif Ryvarden of Oslo, Norway, for identifying many of our polypore collections.

\section{REFERENCES}

ARORA, D., 1986: Mushrooms Demystified. Second Edition. Ten Speed Press, Berkeley, California. 959 pp.

BERKELEY, M.J., 1859: Fungi, in J.D. Hooker, The Botany of the Antarctic voyage of H.M. discovery ships Erebus and Terror in the years 1839-1843. Part III. Flora Tasmanide. Vol. 2. Monocotyledones and Acotyledones. Lovell Reeve, London: 241-282.

BOUgHeR, N.L. \& SYME, K., 1998: Fungi of Southern Australia. University of Western Australia Press, Nedlands, WA. $391 \mathrm{pp}$.

COURTECUISSE, R. \& DUHEM, B., 1995: Mushrooms and Toadstools of Britain and Europe. HarperCollins, London. 480 pp.

CUnNINGHAM, G.H., 1963: The Thelephoraceae of Australia and New Zealand. Bulletin of the New Zealand Department of Scientific and Industrial Research 145: 1-359.

Cunningham, G.H., 1965: Polyporaceae of New Zealand. Bulletin of the New Zealand Department of Scientific and Industrial Research 164: 1-304.

Fuhrer, B.A., 2001: A Field Companion to Australian Fungi. Revised Edition. Bloomings Books, Hawthorn, Victoria. $162 \mathrm{pp}$.
FuHrer, B.A. \& Robinson, R., 1992: Rainforest Fungi of Tasmania and South-2East Australia. CSIRO, East Melbourne, Victoria. $95 \mathrm{pp}$.

Gates, G.M. \& RATKOWSKY, D.A., 2003: The fungal genus Lentinellus in Tasmania. The Tasmanian Naturalist 125: 9-13.

GRGURINOVIC, C.A., 1997: Larger Fungi of South Australia. The Botanic Gardens of Adelaide and State Herbarium and the Flora and Fauna of South Australia Handbooks Committee, Adelaide. 725 pp.

Grgurinovic, C.A., 2003: The Genus Mycena in South-Eastern Australia. Fungal Diversity Press, Hong Kong. 329 pp.

GRGURINOVIC, C.A. \& MALLETT, K. (Eds), 1996: Fungi of Australia, Vol. 1A. Australian Biological Resources Study, Canberra. 413 pp.

Hongo, T. \& Milis, A.K., 1988: Five noteworthy larger fungi new to Tasmania, Australia. Transactions of the Mycological Society of Japan 29: 351-357.

HoOD, I.A. 1992: An Illustrated Guide to Fungi on Wood in New Zealand. Auckland University Press, Auckland, New Zealand. 424 pp.

HoOD, I.A. 2003: An Introduction to Fungi on Wood in Queensland. University of New England, Armidale, NSW. 388 pp.

KIRK, P.M., CANNON, P.F., DAVID, J.C. \& STALPERS, J.A., 2001: Dictionary of the Fungi, 9th edition. CAB International, Wallingford, Oxfordshire. $655 \mathrm{pp}$.

MACDONALD, R. \& WeSTERMAN, J., 1979: A Field Guide to Fungi of South-Eastern Australia. Nelson, Melbourne. $153 \mathrm{pp}$.

MALleTt, K. \& GRGurinovic, C.A. (Eds), 1996: Fungi of Australia, Vol. 1B. Australian Biological Resources Study, Canberra. 405 pp.

Marks, G.C., Fuhrer, B.A. \& Walters, N.E.M. (Huebner, M.L., ed.), 1982: Tree Diseases in Victoria. Forests Commission Victoria, Melbourne. 149 pp.

May, T.W., Milne, J., Shingles, S. \& Jones, R.H., 2003: Catalogue and Bibliography of Australian Fungi 2. Basidiomycota p.p. \& Myxomycota p.p. (Fungi of Australia, Volume 2B). Australian Biological Resources Study, Canberra. $452 \mathrm{pp}$.

MAY, T.W. \& WOOD, A.E., 1997: Catalogue and Bibliography of Australian Macrofungi 1. Basidiomycota p.p. (Fungi of Australia, Volume 2A). Australian Biological Resources Study, Canberra. 348 pp.

MCCANN, I.R., 2003: Australian Fungi Illustrated. Macdown Productions, Vermont, Victoria. 128 pp.

MCNABB, R.F.R., 1965: Taxonomic studies in the Dacrymycetaceae. V. Heterotextus Lloyd. New Zealand Journal of Botany 3: 215-22.

Mills, A.K., MaY, T.W., Fuhrer, B.A., RatKowsky, D.A. \& RATKOWSKY, A.V., 1997: Claustula: the forgotten phalloid. The Mycologist 11: 31-35.

Moncalyo, J.-M., Vilgalys, R., RedHead, S.A., JohnSon, J.E., JaMES, T.Y., Aime, M.C., HOFSTETTER, V., VerDUIN, S.J.W., LARSSON, E., BARONI, T.J., THORN, R.G., JACOBSSON, S., CLÉMENÇON, H. \& MilleR, O.K., Jr., 2002: One hundred and seventeen clades of euagarics. Molecular Phylogenetics and Evolution 23: 357-400.

PERSOON, C.H., 1801. Synopsis methodica fungorum. Hendricus Dietrich, Göttingen, Germany. 706 pp.

PETERSEN, R.H., 1988: The clavarioid fungi of New Zealand. Bulletin of the New Zealand Department of Scientific and Industrial Research 236: 1-170.

RATKOWSKY, D.A. \& GATES, G.M., 2002: A preliminary census of the macrofungi of Mount Wellington, Tasmania - the Agaricales. Papers and Proceedings of the Royal Society of Tasmania 136: 89-100.

RoBINSON, R., 2003: Fungi of the South-West Forests. Department of Conservation and Land Management, Kensington, Western Australia. 72 pp.

Shepherd, C.J. \& TOtTerdell, C.J., 1988: Mushrooms and Toadstools of Australia. Inkata Press, Melbourne and Sydney. 162 pp. 
VellingA, E.C., 2003: Chlorophyllum and Macrolepiota (Agaricaceae) in Australia. Australian Systematic Botany 16: 361-370.
YOUNG, A.M., 2000: Common Australian Fungi. Revised Edition. University of New South Wales Press, Sydney. 154 pp.

\section{APPENDIX 1 \\ Species descriptions of Mt Wellington non-gilled Basidiomycetes}

\section{[Agaricales]}

Clavaria amoena Zoll. \& Moritzi-A simple, i.e., unbranched or at most sparingly branched, yellow, robust, club-like coral fungus. Illustrations - Shepherd \& Totterdell (1988, p. 127), as Clavulinopsis amoena; Fuhrer (2001, p. 88); McCann (2003, p. 85).

Clavaria aurantia Cooke \& Massee - Short, slender, simple orange clubs characterise this species, which may be confused with the more robust Clavaria miniata (q.v.) or with Ramariopsis depokensis (see Bougher \& Syme 1998, pp. 336-7), the latter differing in microscopic details. Illustration - Robinson (2003, p. 37), as Clavulinopsis aff. aurantia.

Clavaria miniata Berk. - Simple clubs characterise this relatively robust orange or red club-like coral fungus. Illustrations - Macdonald \& Westerman (1979, p. 101), as Clavulinopsis miniata; Young (2000, Plate 5), as Clavulinopsis miniata; Fuhrer (2001, p. 89); McCann (2003, p. 85).

Clavaria zollingeri Lév. - This multi-branched, violet or pink-lilac coral fungus may be confused with the similarly-coloured and branched Ramaria versatilis Quél. However, the white spores of the genus Clavaria distinguish it from the ochre-spored genus Ramaria. Illustrations - Fuhrer \& Robinson (1992, pp. 62-3); May et al. (2003, plate 12).

Fistulina hepatica (Schaeff. : Fr.) Fr. - The 'Beefsteak Fungus' is a cosmopolitan, fleshy, pinkish brown, bracketforming polypore with an unusual hymenium that is made up of separable tubes. The tubes and pores are bright pink, becoming brown with age. Illustrations - Shepherd \& Totterdell (1988, p. 130); Bougher \& Syme (1998, pp. 318-9); Fuhrer (2001, p. 116); May et al. (2003, plate 15); McCann (2003, p. 82); Robinson (2003, p. 49).

Lycoperdon perlatum Pers. : Pers. - This brown species, with a globose fruit body and prominent sterile base, is usually found on soil. Confusion with L. pyriforme (q.v.) is possible, but that species has smaller spores with less definite spines. Illustration - Shepherd \& Totterdell (1988, p. 115).

Lycoperdon pyriforme Schaeff. : Pers. - The pear-shaped fruit body, with a greatly reduced sterile base, is usually found on wood. The spores are almost smooth. Illustrations - Fuhrer \& Robinson (1992, p. 66); Hood (1992, fig. 26); Young (2000, plate 17); May et al. (2003, plate 27); McCann (2003, p. 100).

Macrotyphula juncea (Fr. : Fr.) Berthier - This threadlike fungus is almost inconspicuous amongst the leaves and small twigs on which it grows. The light-coloured, fertile upper portion contrasts with the brown sterile base. Illustrations - Fuhrer (2001, p. 85); McCann (2003, p. 87).
[Boletales]

Boletellus obscurecoccineus (Höhn.) Singer - The deep pink pileus and stipe contrast with the non-bruising yellow tubes and pores. The stipe is long, slender and squamulose. Illustrations - Shepherd \& Totterdell (1988, p. 104); Fuhrer \& Robinson (1992, p. 60); Bougher \& Syme (1998, pp. 304-5); Fuhrer (2001, p. 80); Robinson (2003, p. 33).

Boletus tasmanicus Hongo \& A.K. Mills - This medium to large bolete is characterised by its dry, dark reddish brown, finely velvety or finely roughened pileus, yellowish olivaceous tubes with reddish pores, and a subfusoid, reddish brown stipe with faint reticulations. Pores, tubes and stipe bruise blue upon cutting. Illustration - Hongo \& Mills (1988, p. 354).

Calostoma fuscum (Berk.) Massee - A puffball in which the peridium is supported by a network composed of strands of gelarinised tissue. The more or less spherical spore sac is protected by a reddish brown, tough, outer cap that falls off at maturity, exposing the thin-walled, orangemouthed sac. Illustrations - Shepherd \& Totterdell (1988, p. 123); Bougher \& Syme (1998, pp. 112-3); Fuhrer (2001, p. 94); McCann (2003, p. 102).

Fistulinella mollis Watling - An extremely soft, sticky, bolete with pileus colours varying through a range of creams, buffs and browns. The tubes and pores are usually pink. Illustrations - Bougher \& Syme (1998, pp. 306-7); Fuhrer (2001, pp. 79 and 81); McCann (2003, p. 64).

Podoserpula pusio (Berk.) D.A. Reid - The buff-coloured, soft upper surface contrasts with the pink hymenial surface and stipe. An unusual species, having a multitiered structure on a central stipe, although it can occur with a shelf-like growth form. Illustrations - Shepherd \& Totterdell (1988, p. 130), as Cantharellus pusio; Grgurinovic \& Mallett (1996, fig. 28); Bougher \& Syme (1998, pp. 326-7); Fuhrer (2001, p. 132); McCann (2003, p. 66); Robinson (2003, p. 45).

Scleroderma cepa Pers. : Pers. - The genus is readily recognised and separated from other 'puffballs' and 'earthballs' by its yellow-brown, hard outer peridium and olivaceous to violaceous gleba. Frequently found in soil alongside roads, or in dry sclerophyll environments. Illustrations - Macdonald \& Westerman (1979, p. 135), as S. flavidum; Shepherd \& Totterdell (1988, p. 122), as S. flavidum; Grgurinovic \& Mallett (1996, fig. 32); May et al. (2003, plate 51).

[Cantharellales]

Cantharellus concinnus Berk. - Previously considered an Australian variety of a worldwide species, it is recognised by its apricot-orange colours, funnel shape, and shallow, decurrent lamellae that are often forked or tend to 
anastomose. Illustrations - Shepherd \& Totterdell (1988, p. 130), as C. cinnabarina var. australiensis, Fuhrer \& Robinson (1992, p. 24), as C. cibarius var. australiensis, Grgurinovic \& Mallett (1996, fig. 46), as C. cibarius var. australiensis, Bougher \& Syme (1998, pp. 312-3), as C. aff. cinnabarina var. australiensis, Young (2000, Plate 4); McCann (2003, p. 65), as C. cibarius; Robinson (2003, p. 15), as C. aff. cinnabarina var. australiensis.

Clavulina cristata (Holmsk. : Fr.) J. Schröt. - This is a white or whitish species group with very fine, crested branch tips. The genus Clavulina is differentiated from Clavaria in having subglobose spores almost completely filled with a guttation drop and 2-spored basidia with incurved sterigmata. Illustration - McCann (2003, p. 86).

Clavulina rugosa (Bull. : Fr.) J. Schröt. - A greyish, branched, sturdy, rugulose species group. Illustrations - Fuhrer (2001, p. 87); McCann (2003, p. 86).

Hydnum repandum L. : Fr. - Pileus very variable with a range of colours from off-white through various shades of buff and brown. The spore-bearing spines may be up to $5 \mathrm{~mm}$ long. Illustrations - Shepherd \& Totterdell (1988, p. 131); Fuhrer \& Robinson (1992, p. 69), a dark form cited as $H$. aff. repandum; Grgurinovic \& Mallett (1996, fig. 45); Young (2000, plate 8, as $H$. crocidens); Fuhrer (2001, p. 107); May et al. (2003, plate 14); McCann (2003, p. 72); Robinson (2003, p. 41)

\section{[Dacrymycetales]}

Heterotextus peziziformis (Berk.) Lloyd - A very common unbranched, often top-shaped, yellow 'jelly fungus', found at all altitudes on wet, decaying twigs, branches and logs. Its separation from the almost identical $H$. miltinus (Berk.) McNabb is based on microscopic characters (see McNabb, 1965). Illustrations Macdonald \& Westerman (1979, p. 141); Fuhrer \& Robinson (1992, p. 81); Hood (1992, fig. 26); McCann (2003, p. 91), as H. miltinus; Robinson (2003, p. 57).

\section{[Hymenochaetales]}

Coltricia cinnamomea (Jacq.) Murrill - Recognised by its tough, cinnamon-brown, concentrically zoned pileus with coarse, radiating fibrils and a hymenial surface of small, polygonal pores. Illustrations - Bougher \& Syme (1998, pp. 316-7), as Coltricia oblectans, Young (2000, plate 21), as Polyporus oblectans, May et al. (2003, plate 22); McCann (2003, p. 85).

Phellinus wahlbergii (Fr.) D.A. Reid - A concolorous dark brown, chestnut, bay, umber or rusty brown, hard and persisting polypore, it is usually found at the base of dead or dying standing trees. Illustrations - Hood (1992, figs. 56-8); McCann (2003, p. 80).

[Phallales]

Aserö rubra Labill. - A red, starfish-like stinkhorn that emerges from a 'myco-egg', the fertile area blackish and concentrated near the centre of the arms, which sit on top of a pinkish white sterile column. Illustrations - Shepherd \& Totterdell (1988, p. 120); Grgurinovic \& Mallett (1996, fig. 23); Grgurinovic (1997, plate 28c); Young (2000, plate 2); Fuhrer (2001, pp. 103);
May et al. (2003, plate 35); McCann (2003, p. 94). Beenakia dacostae D.A. Reid - A small, soft, whitish stipitate fungus with the basidia borne on spines. It is often found in dry, sheltered areas in wet forests, such as beneath logs. Despite the spines, the genus is not considered to be related to Hydnum. Illustration - Fuhrer \& Robinson (1992, p. 63).

Claustula fischeri K.M. Curtis - Characterised by a white 'mycoegg' with violet hues. The endoperidium is a thick gelatinous layer surrounding the white, chambered receptacle enclosing the brown spore mass. Illustration - Mills et al. (1997, p. 33).

Geastrum triplex Jungh. - This 'Earthstar' is a form of puffball in which the pinkish or brownish outer peridium splits into 5-8 rays. The inner peridium is a thin, light brown, almost globose sac enclosing the spore-bearing gleba. Illustrations - Macdonald \& Westerman (1979, p. 133); Shepherd \& Totterdell (1988, p. 116); Fuhrer \& Robinson (1992, p. 66), as G. indicum; Grgurinovic \& Mallett (1996, fig. 31), as G. indicum; Fuhrer (2001, p. 95), as $G$. indicum; May et al. (2003, plate 25) McCann (2003, p. 96), as G. indicum.

Ramaria botrytis (Pers.:Fr.) Ricken var. holorubella (G.F. Atk.) Corner - The ochre-coloured spore print of this genus separates it from the white-spored genera Clavaria and Clavulina. The fruit body of this cauliflower-like species is mainly buff and tan, with pink to vinaceous tips to the branches. Illustration - Fuhrer (2001, p. 92), as $R$. holorubella. The photograph attributed to $R$ sinapicolor, a synonym of $R$. lorithammus, in Shepherd \& Totterdell (1988, p. 129), is probably of $R$. botrytis.

Ramaria lorithamnus (Berk.) R.H. Petersen - The slender, yellow stems of this species distinguish it from others of the genus. Illustrations - Petersen (1988, plate 2-20); McCann (2003, p. 87). The illustration in Shepherd \& Totterdell (1988, p. 129), as R. sinapicolor, a synonym of $R$. lorithamnus, is a misidentification.

Ramaria ochraceosalmonicolor (Cleland) Corner - Probably the most frequently encountered Ramaria in Tasmania with a cauliflower-like habit, this species is very variable in colour, combining various shades of salmon-pink, yellow and orange. In its most typical form, the branches are salmon-pink coloured and the apices yellow-ochre. Illustrations - Macdonald \& Westerman (1979, p. 103); Bougher \& Syme (1998, pp. 332-3); McCann (2003, p. 87); Robinson (2003, p. 37). The photograph attributed to $R$. aurea in Shepherd \& Totterdell (1988, p. 128) is probably of the present species, whereas the one attributed to $R$. ochraceosalmonicolor on the same page may be of some other species.

[Polyporales]

Amauroderma rude (Berk.) Torrend - A brown polypore that may have a central or an excentric stipe, or grow shelf-like from a woody substrate. Fertile surface white, turning red quickly upon injury, eventually becoming black. Illustrations - Marks et al. (1982, p. 84); Young (2000, plates 1 and 14); Fuhrer (2001, pp. 113); May et al. (2003, plate 18); McCann (2003, p. 74).

Antrodiella citrea (Berk.) Ryvarden - A yellow resupinate polypore, with the brightness of a 'highlighter' pen, sometimes with some shelf development. Illustration - McCann (2003, p. 75), as A. citra.

Antrodiella zonata (Berk.) Ryvarden - A polypore with an 
apricot-pink, irpicoid (i.e., having broken or irregular spines and grooves) fertile surface, tending to form tiers and cover large areas of the trunks of standing dead trees. The abhymenial surface may have distinct, concentric zones. Previously known by the synonyms Irpex brevis or Irpex zonatus. Illustrations - Grgurinovic \& Mallett (1996, fig. 43); McCann (2003, p. 73).

Aurantiporus pulcherrimus (Rodway) P.K. Buchanan \& Hood - A soft, strawberry-red bracket, often but not exclusively found on dead myrtle (Nothofagus cunninghamii) in wet forests. Illustrations - Marks et al. (1982, p. 87), as Tyromyces pulcherrimus; Fuhrer \& Robinson (1992, p. 79); McCann (2003, p. 79).

Australoporus tasmanicus (Berk.) P.K. Buchanan \& Ryvarden - This bracket fungus is noteworthy for the small area of its usually dark brown abhymenial surface relative to its pale brown, whitish or pinkish hymenial surface. Illustration - Fuhrer \& Robinson (1992, p. 76).

Byssomerulius corium (Pers.:Fr.) Parmasto - Whitish, sometimes with pale brown hues, this thin, sheetforming polypore has varying amounts of development of shelf-like growth and a soft, almost tissue-like texture. Usually on small twigs and branches. Illustrations - Cunningham (1963, plate V, fig. 3), as Merulius corium; Hood (1992, fig. 32), as Meruliopsis corium.

Fomes hemitephrus (Berk.) Cooke - A common hoofshaped polypore on wood, whitish in youth, becoming browner with age. The hymenial and abhymenial surfaces are separated internally by a narrow but clearly defined orange zone. It may be confused with Ganoderma applanatum (q.v.), but the hymenial surface doesn't bruise as markedly as that of the latter species. Illustrations - Marks et al. (1982, p. 88), as Heterobasidion hemitephrum; Fuhrer \& Robinson (1992, p. 76), as Fomitopsis hemitephrum; Mallett \& Grgurinovic (1996, fig. 19), as Fomitopsis hemitephra; May et al. (2003, plate 43).

Fomitopsis lilacinogilua (Berk.) T.E. Wright \& J.R. Deschamps - Its lilac colouration distinguishes this fungus from all other polypores found on logs anmd stumps in Tasmania. Illustrations - Macdonald \& Westerman (1979, p. 115), as Trametes lilacino-gilva; McCann (2003, p. 78).

Ganoderma applanatum (Pers.) Pat. - One of the bestknown polypores worldwide, the 'Artist's Conk' is a large brown, bracket-forming fungus noted for its white hymenial surface that readily bruises brown when marked. Illustrations - Macdonald \& Westerman (1979, p. 109); Shepherd \& Totterdell (1988, p. 135); Fuhrer \& Robinson (1992, p. 77); Young (2000, plate 15); McCann (2003, p. 75); Robinson (2003, p. 47).

Gloeoporus taxicola (Pers.:Fr.) Gilb. \& Ryvarden - A soft, resupinate polypore with the hymenial surface made up of purple-vinaceous folds and reticulations, the growing edge much paler. Found on the undersides of wet, dead logs. Illustration - Fuhrer \& Robinson (1992, pp. 72-3), as Merulius ravenelii.

Grifola colensoi (Berk.) G. Cunn. - The compound fruit body, up to $40 \mathrm{~cm}$ diameter, is made up of numerous, large overlapping lobes up to $15 \mathrm{~cm}$ long radiating outwards from a common attachment. The abhymenial surface is brown to blackish, whereas the hymenial surface is cream to buff at first, becoming darker with age. Illustration - Shepherd \& Totterdell (1988, p. 136), as $G$. aff. frondosa. Many or all Tasmanian records of $G$. frondosa are probably misidentifications of $G$. colensoi.

Junghuhnia rhinocephala (Berk.) Ryvarden - The coffee, bay, chestnut, or rusty colours of this small shelf-like or sheet-forming polypore, and especially its distinctive, pleasant, sweet odour, persisting long after drying, make this species recognisable in the field. Microscopically, the abundant crystal-coated 'metuloids' aid in identification. Illustrations - Berkeley (1859, plate 182, fig. 8), as Polyporus rhinocephalus; Hood (1992, fig. 70), as Trichaptum rhinocephalum.

Mycoacia subceracea (Wakef.) G. Cunn. - Forming golden yellow patches on the undersides of fallen branches or small logs, this resupinate fungus has its spore-bearing basidia located on small spines. Illustrations - Fuhrer (2001, p. 109); McCann (2003, p. 72).

Neolentiporus maculatissimus (Lloyd) Rajchenb. - A species that forms medium-sized brackets on the sides of trees and logs, the pores of the hymenial surface often exceeding $1 \mathrm{~mm}$ diameter, with the brownish abhymenial surface varying from almost smooth in youth to markedly scaly. Illustrations - Fuhrer (2001, p. 121); May et al. (2003, plate 48).

Podoscypha petalodes (Berk.) Pat. - Forming orangy brown, leathery rosettes usually near the base of trees, this fungus has concentric bands on its abhymenial surface and a smooth hymenial surface. Illustrations - Fuhrer (2001, p. 133); May et al. (2003, plate 59); McCann (2003, p. 83).

Polyporus melanopus (Sw.:Fr.) Fr. - A tough, leathery polypore on wood with a dark brown stipe, white hymenial surface and a smooth, off-white, brown or dark blood-red pileus. Illustrations - Hood (1992, fig. 91); McCann (2003, p. 81), as Polyporus sp.

Postia caesia (Schrad.:Fr.) P. Karst. - This is a species complex, the species of which have small, sausage-shaped spores. All forms, whether soft and spongy, or firm and thin, are sessile on wood and turn greenish blue when bruised. Australian and New Zealand forms described under Polyporus setiger Cooke belong to this complex. Its appropriate generic position as a Postia, Tyromyces or an Oligoporus is yet to be determined. Illustrations - Hood (1992, fig. 81), as Tyromyces setiger, Courtecuisse \& Duhem (1995, fig. 100), as Oligoporus caesius, Hood (2003, fig. 83), as Tyromyces setiger.

Postia dissecta (Lév.) Rajchenb. - A thin polypore with individual fruit bodies rarely exceeding $3 \mathrm{~cm}$ diameter, forming tiered shelves often at the end of cut logs. Pileus brownish, often with concentric bands, the hymenial surface white. Illustration - Hood (1992, fig. 93), as Polyporus exiguus.

Postia pelliculosa (Berk.) Rajchenb. - A spongy polypore with a brown, hairy abhymenial surface and a white or pinkish hymenial surface. It also occurs with a black, hairy abhymenial surface and a yellow hymenial surface. Illustrations - Marks et al. (1982, p. 87), as Tyromyces pelliculosus; Hood (1992, fig. 82); McCann (2003, p. 79).

Pycnoporus coccineus (Fr.) Bondartsev \& Singer - A polypore that forms conspicuous orange-red brackets or shelves on dead wood. Illustrations - Macdonald \& Westerman (1979, p. 113), as P. cinnabarinus; Bougher \& Syme 
(1998, pp. 330-1); Fuhrer (2001, p. 127); May et al. (2003, plate 50); Robinson (2003, p. 53); McCann (2003, p. 78 ).

Ryvardenia campyla (Berk.) Rajchenb. - A variable polypore species that often forms a rosette of overlapping tongueshaped lobes. Its colour may be white, as in the type specimen, or range through various shades of brown and black, and the surface may vary from smooth to rugose. Illustrations - Cunningham (1965, fig. 15), as Grifola campyla; Marks et al. (1982, p. 88), as Grifola campyla; McCann (2003, p. 76).

Ryvardenia cretacea (Lloyd) Rajchenb. - A very large bracket on standing and fallen trees in wet forests, the abhymenial surface is variably coloured, being greyish, off-white or pale brown with a white hymenial surface. Although firm with a chalky texture in youth, the fungus becomes waterlogged in age and falls to the ground as an insect-riddled mass after one or two seasons. Illustrations - Marks et al. (1982, p. 86), as Piptoporus cretaceus; Fuhrer (2001, p. 120).

Trametes hirsuta (Wulfen:Fr.) Lloyd - A polypore with a grey, off-white or pallid brown, hairy abhymenial surface and a white hymenial surface. Illustration - Fuhrer (2001, p. 128).

Trametes versicolor (L.:Fr.) Lloyd - One of the best-known polypores worldwide, the thin, many-zoned abhymenial surface can have a myriad of colours. Illustrations Macdonald \& Westerman (1979, p. 107); Hood (1992, figs. 110-1); Bougher \& Syme (1998, pp. 340-1); Fuhrer (2001, p. 129); McCann (2003, p. 78).

Tyromyces merulinus (Berk.) G. Cunn. - This is an orangered, usually resupinate polypore, but is also found with some shelf-like growth. Illustrations - Fuhrer \& Robinson (1992, p. 78); Hood (1992, fig. 78).

[Russulales]

Clavicorona piperata (Kauffman) Leathers \& A.H. Sm. - This whitish, pale pink, pale fawn or pale grey species with a peppery taste is separable from other white-spored coral fungi by its habit on decaying wood and its unique branching pattern, each tier or whorl producing up to six branches, giving it a candelabra-like appearance. It is believed (see Bougher \& Syme 1998) that the similarappearing Clavicorona pyxidata (Pers. : Fr.) Doty may not occur in Australia and that Australian records of that species may be misidentifications of the present species. Another species reputed to occur in Australia is Clavicorona colensoi (Berk.) Corner, differing in its fainter or delayed peppery taste and its finer stems and branches. Some records of this species may just be small representatives of $C$. piperata. Illustrations - Macdonald \& Westerman (1979, p. 99), as C. pyxidata; Shepherd \& Totterdell (1988, p. 126), as C. pyxidata; Fuhrer \& Robinson (1992, p. 64), as C. aff. piperata, but which may be C. colensoi; Bougher \& Syme (1998, pp. 314-5); Fuhrer (2001, p. 86); McCann (2003, p. 85 , lower left and lower right, the latter possibly $C$. colensot); Robinson (2003, p. 37).

Mucronella pendula (Massee) R.H. Petersen - Found on surfaces of cut logs or on their sheltered undersides, these small, white, stalactite-like oddities may form small, pendulous colonies. Illustrations - Grgurinovic \& Mallett (1996, fig. 47); Shepherd \& Totterdell (1988, p. 129), as Myxomycidium pendulum; Fuhrer
(2001, p. 90); May et al. (2003, plate 20); McCann (2003, p. 72).

Stereum hirsutum (Willd.:Fr.) Pers. - A very variable shelf-like 'thelephore' with yellow, orange and brownish colours. The abhymenial surface is densely covered with soft hairs. Illustrations -Shepherd \& Totterdell (1988, p. 133), as S. complicatum; Hood (1992, fig. 39); Mallett \& Grgurinovic (1996, fig. 20); Bougher \& Syme (1998, pp. 338--9); Fuhrer (2001, p. 135); McCann (2003, p. 83); Robinson (2003, p. 45).

Stereum illudens Berk. - The purple-vinaceous shades of the hymenial surface contrast with the brown zones of the abhymenial surface. Illustrations - Macdonald \& Westerman (1979, p. 121), as Xylobolus illudens; Fuhrer \& Robinson (1992, p. 74-5); Fuhrer (2001, p. 136); May et al. (2003, plate 58); McCann (2003, p. 84).

Stereum ostrea (Blume \& Nees:Fr.) Fr. - Generally larger and thinner than $S$. hirsutum, which this species resembles due to its yellow-orange colours, the hairs on the upper surface are finer and less dense. Illustrations - Macdonald \& Westerman (1979, p. 119); Fuhrer \& Robinson (1992, p. 72); Hood (1992, plate 3), as S. fasciatum; Hood (2003, fig. 62); May et al. (2003, plate 57); McCann (2003, p. 84).

Stereum rugosum Pers. - The grey lower surface helps distinguish this species from $S$. illudens in the field. Unlike European representatives of the species, Tasmanian specimens do not exude a red latex when injured. Illustrations - Fuhrer (2001, pp. 131 and 137); McCann (2003, p. 84).

[Thelephorales]

Phellodon niger (Fr.:Fr.) P. Karst. - Growing close to the soil amongst litter, this blackish, leathery fungus has concentric bands on its abhymenial surface, and a tendency for pilei and stipes to fuse together, often resulting in distorted fruiting bodies. The basidia are located on small spines on the hymenial surface. Illustrations - Shepherd \& Totterdell (1988, p. 131); Fuhrer (2001, p. 110); Robinson (2003, p. 41), as Phellodon aff. niger.

[Tremellales]

Exidia glandulosa (Bull.:Fr.) Fr. - This black, blackish brown or grey-brown, gelatinous or rubbery jelly fungus covers rotting logs and, unlike the related genus Tremella, often has a roughened spore-bearing surface. Illustration - McCann (2003, p. 91).

Pseudobydnum gelatinosum (Scop.:Fr.) P. Karst. - A mycological oddity, this species is a 'jelly fungus' with a spore-bearing surface composed of translucent spines. Illustrations - Macdonald \& Westerman (1979, p. 143); Fuhrer \& Robinson (1992, p. 80); Hood (1992, fig. 22); Fuhrer (2001, p. 142); Young (2000, plate 24), as Tremellodon gelatinosum; McCann (2003, p. 91).

Tremella fimbriata Pers.:Fr. - A brown jelly fungus with lobes that are either flattened or inflated. The spore-bearing surface is smooth, not roughened as in Exidia glandulosa (q.v.). Illustrations - Arora (1986, plate 173), as $T$. foliacea; McCann (2003, p. 92), as T. frondosa.

Tremella fuciformis Berk. - Common on fallen logs in wet forests, the whitish colour of this convoluted jelly fungus differentiates it from other species of the genus. Illustrations - Shepherd \& Totterdell (1988, 
p. 143); Fuhrer \& Robinson (1992, p. 80); Fuhrer (2001, p. 141); May et al. (2003, plate 60); McCann (2003, p. 92).

Tremella mesenterica Retz.:Fr. - Similar to T. fuciformis (q.v.) in its brain-like, convoluted form, but differs in its yellow to orange colours and its preference for drier environments. Illustrations - Shepherd \& Totterdell (1988, p. 143); Grgurinovic \& Mallett (1996, fig. 19); Fuhrer (2001, pp. 138 and 141); May et al. (2003, plate 62); McCann (2003, p. 92); Robinson (2003, p. 57)

\section{APPENDIX 2 \\ Additions and corrections to records of gilled Basidiomycota in Ratkowsky \& Gates (2002)}

\section{[Agaricales]}

Cheimonophyllum candidissimum (Berk. \& M.A. Curtis) Singer - The small, fan-shaped, fruit bodies are white, soft-fleshed, and occur on rotting wood. Illustration - McCann (2003, p. 42).

Dermocybe canaria E. Horak - A medium to large fungus, yellow in all its parts, that turns brown with age. Illustration - McCann (2003, p. 20).

Macrolepiota clelandii Grgur. - This species was listed in Ratkowsky \& Gates (2002) as M. konradii (Huijsman ex P.D. Orton) M.M. Moser. However, Vellinga (2003) showed that the name $M$. konradii, as well as the names $M$. gracilenta (Krombh.) Wasser, $M$. procera (Scop. : Fr.) Singer, and M. mastoidea (Fr. : Fr.) Singer, refer to European species and have been misapplied by Australian authors to what is really a single, native species, $M$. clelandii. Illustrations - see the list in Ratkowsky \& Gates (2002).

Mycena albidofusca Grgur. - This is a small species with a brown pileus and a blister-like or whitish central disc and translucent-striate margin. Illustrations - Grgurinovic (2003, plate 14); McCann (2003, p. 53).

Mycena carmeliana Grgur. - A brown species with orange hues, recognised by its sulcate margin, bleach odour, and orange basal disc. Illustration - Grgurinovic (2003, plate 28).

Mycena mulawaestris Grgur. - A medium-sized species with a dark brown, glutinous pileus. Illustration - Grgurinovic (2003, plate 21).

Mycena nargan Grgur. - A medium to large, conical, darkbrown species, distinguishable by small, white particles that cover the pileus in youth. Illustration - Grgurinovic (2003, plate 23).

Mycena vinacea Grgur. - This species was listed in Ratkowsky \& Gates (2002) as Mycena pura (Pers.:Fr.) P. Kumm. According to Grgurinovic (2003), all Australian records purporting to be $M$. pura are either $M$. vinacea Cleland or another related species, $M$. nullawarrensis Grgur., with the latter not yet known outside Victoria. Tasmanian material fits the description of $M$. vinacea, and, to the two illustrations cited in Ratkowsky \& Gates (2002) as $M$. pura, one can add Grgurinovic (2003, plate 3), McCann (2003, p. 54), and Robinson (2003, p. 25, as $M$. pura).

Pholiota aurivella (Batsch.:Fr.) P. Kumm. - Characterised by a lemon-yellow or golden-brown, thickly glutinous pileus in which dark brown or tawny brown scales are immersed in the gluten layer.
[Russulales]

Lactarius stenophyllus Berk. - Pileus centrally depressed, with lemon-coloured shades and concentric zones that may fade in age or which are sometimes indistinct, lamellae adnate to subdecurrent, close to crowded, yellow with pale peach or apricot hues. Stipe stout, white or tinted pale peach or pale apricot. Latex white, with a bitter aftertaste. Illustration - Berkeley (1859, plate 181 , fig. 8).

Lentinellus hepatotrichus (Berk.) D.A. Reid - This species, in common with the other species of the genus, is characterised by conspicuously serrate or eroded lamellar margins and amyloid, verrucose spores. The sessile, dark brown pileus is generally densely hairy, with tufts of shaggy hairs covering most of the upper surface. Spores small, 3-5 x 3-4 $\mu \mathrm{m}$. A member of the L. ursinus (Fr. : Fr.) Kühner complex and separated from L. pulvinulus (q.v.) mainly by its smaller spores. Illustration - Fuhrer \& Robinson (1992, p. 47), as Lentinellus sp.

Lentinellus omphalodes (Fr.) P. Karst. - This is the only one of the Tasmanian species of the genus with a welldeveloped stipe, which may be central or eccentric. We have recently learned (R.H. Petersen, pers. comm., 7 January 2004) that this species should now be called L. micheneri (Berk. \& M.A. Curtis) Pegler.

Lentinellus pulvinulus (Berk.) Pegler - The sessile, light brown to buff pileus is pubescent near the attachment but tends to be glabrous near the margin. Spores $5-7 \mathrm{x}$ 4-6 $\mu \mathrm{m}$. Believed to be closely related to L. flabelliformis (Bolton : Fr.) Ito. Separated from L. hepatotrichus (q.v.) mainly by its larger spores. 